\title{
How serious are common childhood fears? II. The parent's point of view
}

Citation for published version (APA):

Muris, P. E. H. M., \& Merckelbach, H. L. G. J. (2000). How serious are common childhood fears? II. The parent's point of view. Behaviour Research and Therapy, 38(8), 813-818. https://doi.org/10.1016/S00057967(99)00119-9

Document status and date:

Published: 01/01/2000

DOI:

10.1016/S0005-7967(99)00119-9

Document Version:

Publisher's PDF, also known as Version of record

\section{Please check the document version of this publication:}

- A submitted manuscript is the version of the article upon submission and before peer-review. There can be important differences between the submitted version and the official published version of record.

People interested in the research are advised to contact the author for the final version of the publication, or visit the DOI to the publisher's website.

- The final author version and the galley proof are versions of the publication after peer review.

- The final published version features the final layout of the paper including the volume, issue and page numbers.

Link to publication

\footnotetext{
General rights rights.

- You may freely distribute the URL identifying the publication in the public portal. please follow below link for the End User Agreement:

www.umlib.nl/taverne-license

Take down policy

If you believe that this document breaches copyright please contact us at:

repository@maastrichtuniversity.nl

providing details and we will investigate your claim.
}

Copyright and moral rights for the publications made accessible in the public portal are retained by the authors and/or other copyright owners and it is a condition of accessing publications that users recognise and abide by the legal requirements associated with these

- Users may download and print one copy of any publication from the public portal for the purpose of private study or research.

- You may not further distribute the material or use it for any profit-making activity or commercial gain

If the publication is distributed under the terms of Article $25 \mathrm{fa}$ of the Dutch Copyright Act, indicated by the "Taverne" license above, 


\title{
Shorter Communication
}

\section{How serious are common childhood fears? II. The parent's point of view}

\author{
Peter Muris*, Harald Merckelbach \\ Department of Medical, Clinical, and Experimental Psychology and Department of Psychology, Maastricht University, \\ P.O. Box 616, 6200 MD Maastricht, Netherlands
}

\begin{abstract}
In an earlier study [Muris, P., Merckelbach, H., Mayer, B., \& Prins, E. (1999). How serious are common childhood fears? Behaviour Research and Therapy, in press.], the severity of common childhood fears was explored by means of a structured child interview measuring specific phobias as defined by the Diagnostic and Statistical Manual of Mental Disorders. It was found that in a substantial minority of the children, specific fears reflect clinically significant phobias. The present study examined further the connection between childhood fears and specific phobias by interviewing children's parents. The Diagnostic Interview Schedule for Children was administered to the parents of 160 children aged 4-12 years. In line with our previous study, results indicate that a sizable proportion of children (i.e. 17.6\%) met the full criteria for specific phobia. (C) 2000 Elsevier Science Ltd. All rights reserved.
\end{abstract}

Keywords: Childhood fears; Specific phobias; Parents' report

\section{Introduction}

Survey research has indicated that children report a surprisingly large number of specific fears and there is good evidence to suggest that this is true for a wide variety of cultures. For example, Ollendick, Yang, King, Dong and Akande (1996) found an average number of 17 fears reported by American, Australian, Chinese and Nigerian children. While the high prevalence of fears among children is a well-established fact, it is far from clear how serious

\footnotetext{
* Corresponding author. Tel.: + 31-43-388-1264; fax: + 31-43-88-4155.

E-mail address: p.muris@dep.unimaas.nl (P. Muris).
}

0005-7967/00/\$ - see front matter (C) 2000 Elsevier Science Ltd. All rights reserved.

PII: S0005-7967(99)00119-9 
these fears are (e.g. Ollendick \& King, 1994). To examine the severity of common childhood fears, their connection to clinically defined specific phobias should be considered. A recent study by Muris, Merckelbach, Mayer and Prins (in press a) explored this issue. Fears of 290 children aged 8-13 years were assessed and then their clinical relevance was evaluated by means of a structured diagnostic interview measuring specific phobias (and other anxiety disorders) as defined by the Diagnostic and Statistical Manual of Mental Disorders (DSM; American Psychiatric Association, 1987) criteria. Results showed that in a sizable minority of the children (i.e. 19.6\%), fears reflected specific phobias.

An obvious limitation of the Muris et al. (in press a) study is that it relied on children's selfreports of specific fears and their characteristics. Thus, it may well be the case that especially young children find it difficult to provide articulated information as to the intensity and ramifications of their fears. For this reason, interviewing parents of children might be an useful alternative for collecting data on the link between childhood fears and specific phobias. The present study followed this approach. More specifically, parents were asked to describe their children's specific fears and were then interviewed about the severity of these fears by means of a structured diagnostic interview schedule measuring specific phobias according to DSM criteria.

\section{Method}

Parents of 160 primary school children ( 82 boys and 78 girls) participated in the present study. In most cases, the mother provided information about the child's fears and phobias $(n=136)$. In other cases, the father $(n=10)$ or both parents $(n=14)$ were interviewed 1 .

Ages of the children ranged between 4 and 12 years, with a mean age of 7.5 years $($ S.D. $=2.4)$. The large majority of the children was Caucasian $(99 \%)$. Percentages of children with low, middle or upper socioeconomic background (based on the occupational levels of both parents) were 15,65 and $20 \%$, respectively. About $5 \%$ of the children came from divorced families.

Parents were visited at home. First, they were given a brief checklist on which they had to indicate on a 3-point scale to what extent their children were afraid of the doctor, the dentist, heights, water, tunnels or bridges, elevators, spiders, insects, mice, snakes, birds, dogs, other animals that are not really dangerous, the dark, thunderstorms, and/or blood $(1=$ almost never, $2=$ sometimes, $3=$ often). Next, the diagnostic criteria for specific phobia were checked for children's most intense fears (i.e. fears that were reported to occur often). This was done by means of the parent version of the Diagnostic Interview Schedule for Children (DISC), a highly structured interview that systematically checks the DSM-III-R criteria for emotional disorders in children (National Institute of Mental Health, 1992). Children who met the full DSM-III-R criteria for specific phobia including the 'significant interference with the child's normal functioning' criterion were defined as clinical cases. Children who fulfilled the criteria

\footnotetext{
${ }^{1}$ Children and parents also participated in a study on children's nighttime fears. The results of that study are reported elsewhere.
} 
except for the interference criterion were defined as subclinical cases. Previous research has shown that the DISC possesses adequate test-retest reliability (Schwab-Stone, Fisher, Piacentini, Shaffer, Davis \& Briggs, 1993), sufficient interrater reliability (Shaffer et al., 1993) and acceptable validity (Piacentini, Shaffer, Fisher, Schwab-Stone, Davies \& Gioia, 1993).

\section{Results and discussion}

Table 1 shows the rank order of children's fears based on the checklist ratings of parents. As can be seen, the most common fears were concerned with the dark, spiders and thunderstorms. It should be noted that these fears also rank high in fear hierarchies that are based on children's self-report (Muris, Merckelbach \& Collaris, 1997a; Muris, Merckelbach, Meesters \& Van Lier, 1997b; Muris, Merckelbach, Gadet \& Moulaert, in press b). Furthermore, it should be mentioned that only one significant gender difference was found: parents reported that girls were more often afraid of spiders than were boys $[n=28,35.9 \%$ versus $n=11,13.4 \%$, respectively; $\chi^{2}(1)=11.0, P<0.001$ ].

The DISC interviews with the parents revealed that a substantial proportion of children displayed subclinical symptoms of phobias (see left panel of Table 2). Subclinical manifestations of animal phobias $(n=26,16.3 \%)$, in particular phobias of spiders and dogs and environmental phobias $(n=26,16.3 \%)$, notably phobias of the dark and thunderstorms, were most prevalent. Subclinical blood-injury phobias were less common $(n=11,6.9 \%)$. Again, girls were reported to display subclinical symptoms of spider phobia more frequently than boys $\left(\chi^{2}(1)=4.5, P<0.05\right)$.

When the interference criterion was taken into account (i.e. clinical cases), the prevalence of specific phobias in children was found to be considerably lower than that of subclinical manifestations of specific fears (see the right panel of Table 2). Nevertheless, 28 children $(17.6 \%)$ were found to meet the full criteria for specific phobias. Animal phobias appeared to be the most common type of phobia $(n=16,10.0 \%)$, followed by environmental phobias $(n=$ $10,6.3 \%)$ and blood-injury-illness phobias $(n=2,1.3 \%)$.

The current study was based on the rationale that interviewing parents about their children's specific fears might provide a reliable picture of the severity of these fears. Meanwhile, in literature, indications can be found that under some circumstances, parents' reports may underestimate the problems of their children (Brewin, Andrews \& Gotlib, 1993). Evenso, the frequency of childhood specific phobias that the current study derived from parents' interviews comes very close to that found in our previous study (Muris et al., in press a) relying on children's self-report of phobic symptoms. More specifically, the present study obtained a prevalence rate of $17.6 \%$, whereas in our previous study, $19.6 \%$ of the children met the full diagnostic criteria for specific phobia. Admittedly, the samples of both studies are not completely comparable (e.g. different age groups, socioeconomic status), but at the very least the findings converge on the notion that a substantial minority of common childhood fears should be taken serious as they qualify for a specific phobia. 
Table 1

Rank order of children's fears based on ratings of parents. $\mathrm{N}=160$ (82 boys and 78 girls). ${ }^{*}$ Difference between boys and girls significant at $P<$ 0.001

\begin{tabular}{|c|c|c|c|c|}
\hline & $\begin{array}{l}\text { Number } \\
(\%) \text { of children }\end{array}$ & $\begin{array}{l}\text { Number } \\
(\%) \text { of children that are often afraid }\end{array}$ & $\begin{array}{l}\text { Number } \\
(\%) \text { of boys that are often afraid }\end{array}$ & $\begin{array}{l}\text { Number } \\
(\%) \text { of girls that are often afraid }\end{array}$ \\
\hline (1) The dark & $50(31.3)$ & $34(21.3)$ & $19(23.2)$ & $15(19.2)$ \\
\hline (2) Spiders & $49(30.6)$ & $39(24.4)$ & $11(13.4)$ & $28(35.9)^{*}$ \\
\hline (3) Thunderstorms & $46(28.7)$ & $33(20.6)$ & $14(17.1)$ & $19(24.4)$ \\
\hline (4) Blood & $28(17.5)$ & $19(11.9)$ & $10(12.2)$ & $9(11.5)$ \\
\hline (5) The doctor & $23(14.4)$ & $18(11.3)$ & $6(7.3)$ & $12(15.4)$ \\
\hline (6) The dentist & 19 (11.9) & $12(7.5)$ & $4(4.9)$ & $8(10.3)$ \\
\hline (7) Dogs & $14(8.8)$ & $13(8.1)$ & $8(9.8)$ & $5(6.4)$ \\
\hline (8) Birds & $8(5.0)$ & $8(5.0)$ & $4(4.9)$ & $4(5.1)$ \\
\hline (9) Heights & $8(5.0)$ & $7(4.4)$ & $6(7.3)$ & $1(1.3)$ \\
\hline (10) Elevators & $8(5.0)$ & $4(2.5)$ & $3(3.7)$ & $1(1.3)$ \\
\hline (11) Wasps & $4(2.5)$ & $4(2.5)$ & $2(2.4)$ & $2(2.6)$ \\
\hline (12) Water & $4(2.5)$ & $1(0.6)$ & $1(0.6)$ & $0(0.0)$ \\
\hline (13) Snakes & $2(1.3)$ & $2(1.3)$ & $2(2.4)$ & $0(0.0)$ \\
\hline (14) Tunnels/bridges & $2(1.2)$ & $1(0.6)$ & $1(1.2)$ & $0(0.0)$ \\
\hline (15) Mice & $1(0.6)$ & $1(0.6)$ & $0(0.0)$ & $1(1.3)$ \\
\hline (16) Fishes & $1(0.6)$ & $1(0.6)$ & $0(0.0)$ & $1(1.3)$ \\
\hline
\end{tabular}


Table 2

Prevalence of subclinical and clinical childhood phobias based on diagnostic interview with the parents. $N=160(82$ boys and 78 girls). ${ }^{*}$ Difference between boys and girls significant at $P<0.05$

\begin{tabular}{|c|c|c|c|c|c|c|}
\hline & \multicolumn{3}{|c|}{ Subclinical symptoms } & \multicolumn{3}{|c|}{ Clinical symptoms } \\
\hline & $\begin{array}{l}\text { Number } \\
(\%) \text { of children }\end{array}$ & $\begin{array}{l}\text { Number } \\
(\%) \text { of boys }\end{array}$ & $\begin{array}{l}\text { Number } \\
(\%) \text { of girls }\end{array}$ & $\begin{array}{l}\text { Number } \\
(\%) \text { of children }\end{array}$ & $\begin{array}{l}\text { Number } \\
(\%) \text { of boys }\end{array}$ & $\begin{array}{l}\text { Number } \\
(\%) \text { of girls }\end{array}$ \\
\hline Animal phobias & $26(16.3)$ & $10(12.2)$ & $16(20.5)$ & $16(10.0)$ & $6(7.3)$ & $10(12.8)$ \\
\hline Spiders & $13(8.1)$ & $3(3.7)$ & $10(12.8)^{*}$ & $8(5.0)$ & $2(2.4)$ & $6(7.7)$ \\
\hline Dogs & $6(3.8)$ & $3(3.7)$ & $3(3.8)$ & $3(1.9)$ & $2(2.4)$ & $1(1.3)$ \\
\hline Birds & $4(2.5)$ & $2(2.4)$ & $2(2.6)$ & $3(1.9)$ & $1(1.2)$ & $2(2.6)$ \\
\hline Snakes & $2(1.3)$ & $2(2.4)$ & $0(0.0)$ & $1(0.6)$ & $1(1.2)$ & $0(0.0)$ \\
\hline Wasps & $1(0.6)$ & $0(0.0)$ & $1(1.3)$ & $1(0.6)$ & $0(0.0)$ & $1(1.3)$ \\
\hline Environmental phobias & $26(16.3)$ & $16(19.5)$ & $10(12.8)$ & $10(6.3)$ & $6(7.3)$ & $4(5.1)$ \\
\hline The dark & $13(8.1)$ & $8(9.8)$ & $5(6.4)$ & $7(4.4)$ & $3(3.7)$ & $4(5.1)$ \\
\hline Thunderstorms & $10(6.3)$ & $5(6.1)$ & $5(6.4)$ & $0(0.0)$ & $0(0.0)$ & $0(0.0)$ \\
\hline Heights & $2(1.3)$ & $2(2.4)$ & $0(0.0)$ & $2(1.3)$ & $2(2.4)$ & $0(0.0)$ \\
\hline Water & $1(0.6)$ & $1(1.2)$ & $0(0.0)$ & $1(0.6)$ & $1(1.2)$ & $0(0.0)$ \\
\hline Blood-injury-illness phobias & $11(6.9)$ & $5(6.1)$ & $6(7.7)$ & $2(1.3)$ & $0(0.0)$ & $2(2.6)$ \\
\hline The doctor & $5(3.1)$ & $2(2.4)$ & $3(3.8)$ & $0(0.0)$ & $0(0.0)$ & $0(0.0)$ \\
\hline The dentist & $3(1.9)$ & $2(2.4)$ & $1(1.3)$ & $1(0.6)$ & $0(0.0)$ & $1(1.3)$ \\
\hline Blood & $3(1.9)$ & $1(1.2)$ & $2(2.6)$ & $1(0.6)$ & $0(0.0)$ & $1(1.3)$ \\
\hline
\end{tabular}

\section{Acknowledgements}

Nicole Bogie is thanked for collecting the data.

\section{References}

American Psychiatric Association (1987). Diagnostic and statistical manual of mental disorders (3rd ed. - revised). Washington: American Psychiatric Association.

Brewin, C. R., Andrews, B., \& Gotlib, I. H. (1993). Psychopathology and early experience: a reappraisal of retrospective reports. Psychological Bulletin, 113, 82-98.

Muris, P., Merckelbach, H., \& Collaris, R. (1997a). Common childhood fears and their origins. Behaviour Research and Therapy, 35, 929-937.

Muris, P., Merckelbach, H., Meesters, C., \& Van Lier, P. (1997b). What do children fear most often? Journal of Behavior Therapy and Experimental Psychiatry, 28, 263-267.

Muris, P., Merckelbach, H., Gadet, B. \& Moulaert, V. (in press b). Fears, worries, and scary dreams in 4-12-yearold children: their content, developmental pattern and origins. Journal of Clinical Child Psychology.

Muris, P., Merckelbach, H., Mayer, B. \& Prins, E. (in press a). How serious are common childhood fears? Behaviour Research and Therapy.

National Institute of Mental Health (1992). Diagnostic Interview Schedule for Children (DISC), version 2.3. New York: New York State Psychiatric Institute, Division of Child and Adolescent Psychiatry.

Ollendick, T. H., \& King, N. J. (1994). Fears and their level of interference in adolescents. Behaviour Research and Therapy, 32, 635-638.

Ollendick, T. H., Yang, B., King, N. J., Dong, Q., \& Akande, A. (1996). Fears in American, Australian, Chinese 
and Nigerian children and adolescents: a cross-cultural study. Journal of Child Psychology and Psychiatry, 37, 213-220.

Piacentini, J., Shaffer, D., Fisher, P., Schwab-Stone, M., Davies, M., \& Gioia, P. (1993). The Diagnostic Interview Schedule for Children - revised version (DISC-R). III. Concurrent criterion validity. Journal of the American Academy of Child and Adolescent Psychiatry, 32, 658-665.

Schwab-Stone, M., Fisher, P., Piacentini, L., Shaffer, D., Davies, M., \& Briggs, M. (1993). The Diagnostic Interview Schedule for Children - revised version (DISC-R). II. Test-retest reliability. Journal of the American Academy of Child and Adolescent Psychiatry, 32, 651-657.

Shaffer, D., Schwab-Stone, M., Fisher, P., Cohen, P., Piacentini, J., Davies, M., Conners, K., \& Regier, D. (1993). The Diagnostic Interview Schedule for Children - revised version (DISC-R). I. Preparation, field testing, interrater reliability and acceptability. Journal of the American Academy of Child and Adolescent Psychiatry, 32, 643-650. 